\title{
Will India be the Sixth Country?
}

FOR many years Indians have been deeply troubled by the question of whether or not to possess nuclear weapons. It will be recalled that it was India, through Prime Minister Nehru, who first proposed, in 1954, to the United Nations that there should be a standstill on weapons tests, and this set in motion the long chain of events that led to the Partial Test Ban Treaty. In 1957 Nehru declared: "We are not interested in making atom bombs, even if we have the capacity to do so". By 1964, Indian nuclear science had developed to the state that Prime Minister Shastri could say: "We have the capability of developing nuclear weapons, but we stand committed to use atomic energy only for peaceful purposes". And yet doubts remained that India could forever stay out of the nuclear club. There were clear signs that she was keeping certain options open when she refrained from signing the Non-Proliferation Treaty.

Within the past year there have been one or two exchanges in the Indian Parliament which suggest that something new is about to emerge. Interest in the use of peaceful nuclear explosions is sufficient for Mrs Gandhi to be able to say that India is now studying the feasibility of nuclear detonations for peaceful purposes. Copper-ore extraction by blasting could be the first experiment.

There is not a shadow of doubt that India is technologically capable of developing a nuclear bomb. There is a thriving programme for nuclear power generation including a power station being built in Madras which is of predominantly Indian design and construction. Fissile material presents no major obstacle as there is a good domestic supply of uranium and thorium. Plutonium production from the Madras power station will be subject to no safeguards. Thus, conditions in the near future will be ideal for the development of a nuclear explosive.

Can it be simply a peaceful device? Once the primary skills of designing a nuclear device have been mastered and the device tested in peaceful operations, it would be foolish to suppose that bombs cannot be made without further testing. Since both fission and fusion devices could be used in any extended programme of nuclear explosive engineering, there does not seem to be any reason why India could not develop quite an extensive armoury under the peaceful purposes umbrella. At present there are delivery problems but in the next few years an extensive space programme could easily provide a suitable vehicle.

The omens are not good. If India really wanted to use nuclear explosives purely for peaceful purposes, a well publicised approach to the Soviet Union (the most advanced nation in this technology) for assistance would have made more sense. The provision of explosives by the Soviet Union would have required a variance of the Non-Proliferation Treaty, but this might not have proved difficult to get.

What inhibits a full scale military nuclear programme whether under 'peaceful' auspices or not? Cost is the central issue. Developed countries which have had a nuclear weapons programme have found the economic impact a strain. There is little doubt that $£ 1,000$ million, at least, would be necessary for the most elemental force, and the Indian Gross National Product is only $£ 20,000$ million. One study, by the United States Arms Control and Disarmament Agency, labelled any attempt by India to go nuclear as "economically disastrous".

Even without the dreadful financial burden that nuclear weapons development would impose on India, there are many who believe, for strategic reasons, that India should not get herself embroiled in nuclear armament. There must be the strongest possible doubts that nuclear weapons could alter the military status of the country. Although the target is clearly China at present, there would be little value in a few nuclear weapons against a country so dispersed, and one can only imagine that nuclear weapons would be used in battleground situations on the borders and against a small number of military installations. It is difficult to see how India could win such an exchange and it would be better were she not to create a situation in which it could arise. Further, proliferation by India would be a positive step towards proliferation by several other countries.

One of the neatest and most thought-provoking of epigrams is due to Meister Eckhart: "The greatest power available to man is not to use it". It is distinctly appropriate to the nuclear age and highly relevant to India. This philosophy of "we can but we will not" has played a major role in preventing the spread of nuclear weapons to India in the past. One must hope that those who hold to a policy of self-restraint do not let their guard slip.

\section{Years Ago}

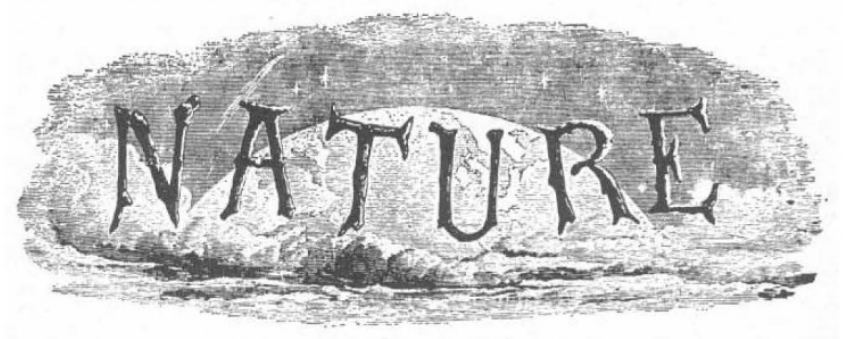

CANADA is doing its part toward the exploration of the Great West. Besides the surveying parties out on the route of the Pacific Railroad, it has special parties in the field in connection with the Geological Survey and the Boundary Commission. Mr. Selwyn, F.G.S., Director of the Survey, and Mr. R. Bell, F.G.S., are at work on the great regions watered by the North Saskatchewan, and Mr. Richardson on the other side of the Rocky Mountains in British Columbia. Mr. G. M. Dawson, Associate of the School of Mines, Geologist of the Boundary Commission, has just completed a survey of the Lake of the Woods and its neighbourhood, and is now exploring the plains westward of Pembina. All these parties are provided with the means of making collections in the botany and zoology of the regions explored.

From Nature, 8, 497, October 9, 1873. 